\title{
Kootenai River white sturgeon: synthesis of two decades of research
}

\author{
V. L. Paragamian* \\ Idaho Department of Fish and Game, Coeur d'Alene, Idaho 83815, USA
}

\begin{abstract}
Little information is available on the Kootenai River white sturgeon Acipenser transmontanus population prior to the completion of Libby Dam (Montana, USA) in 1972. Regulation of the Kootenai River by the dam significantly lowered discharge and reduced river temperatures during the white sturgeon spawning season. The population became recruitment limited and was listed as endangered under the US Endangered Species Act in 1994. An international recovery team between the USA and Canada was formed to develop a recovery plan and recommend recovery measures. This paper is a synthesis of research that followed. Population studies estimated an abundance of 1000 adults declining at about $4 \%$ annually. Through conservation culture hatchery stockings in the early 1990s, survival was found to be about $65 \%$ in the first year and $90 \%$ thereafter; consequently, hatchery fish soon dominated the population. Wild white sturgeon spawning occurred in spring when the river warmed to $\geq 8^{\circ} \mathrm{C}$ but took place over sand substrates which were thought to be unsuitable for incubation and rearing. Recruitment failures continued to drive the decline despite augmented discharge, which was of little value to white sturgeon spawning. Evaluation of spawning habitat and fluvial processes confirmed that cobbles and gravels were present at most spawning locations but were buried under sediment. Although discharges $\geq 1600 \mathrm{~m}^{3} \mathrm{~s}^{-1}$ for a period of $2 \mathrm{wk}$ would likely scour fine substrates and provide more suitable spawning and rearing conditions, such a measure would be socially and politically unacceptable. Thus, support should be given to a habitat management plan that restores suitable substrates that help promote enhanced survival of embryos and larvae.
\end{abstract}

KEY WORDS: White sturgeon · Kootenai River · Endangered fish · Idaho Resale or republication not permitted without written consent of the publisher

\section{INTRODUCTION}

In Idaho (USA), white sturgeon Acipenser transmontanus are native to the Snake, Clearwater, Salmon, and Kootenai Rivers (Simpson \& Wallace 1982). The Kootenai River (spelled Kootenay in Canada) is trans-boundary with Montana, USA, and British Columbia (BC), Canada (Fig. 1). Records of the white sturgeon stock in the Idaho reach of the Kootenai River prior to the completion of Libby Dam (Montana) in 1972 exist only in the form of anecdotal information, archived photos, and news releases. In Montana, a popular fishing site called 'The Sturgeon Hole' was the focus of unpublished records of a local angler in 1970 (V. Applegate, unpublished letter to
Montana Department of Fish Wildlife and Parks). The Montana angler caught a total of 30 white sturgeon from the 'sturgeon hole,' which varied from 48.3 to $190.5 \mathrm{~cm}$ total length (TL), with $66 \%$ being $<91.4 \mathrm{~cm}$. Most of Applegate's catch were likely immature fish, with only 6 individuals over $109.2 \mathrm{~cm}$ TL.

In 1966, the US Army Corps of Engineers (USACE) began construction of Libby Dam on the Kootenai River, near Jennings, Montana, for flood control and hydropower (Fig. 1). The dam was completed in 1972, and Koocanusa Reservoir was impounded in 1973 and completely filled in 1974. From 1973 through 1977 sturgeon fishing permit holders in BC caught a total of 50 white sturgeon from the South Arm of Kootenay 


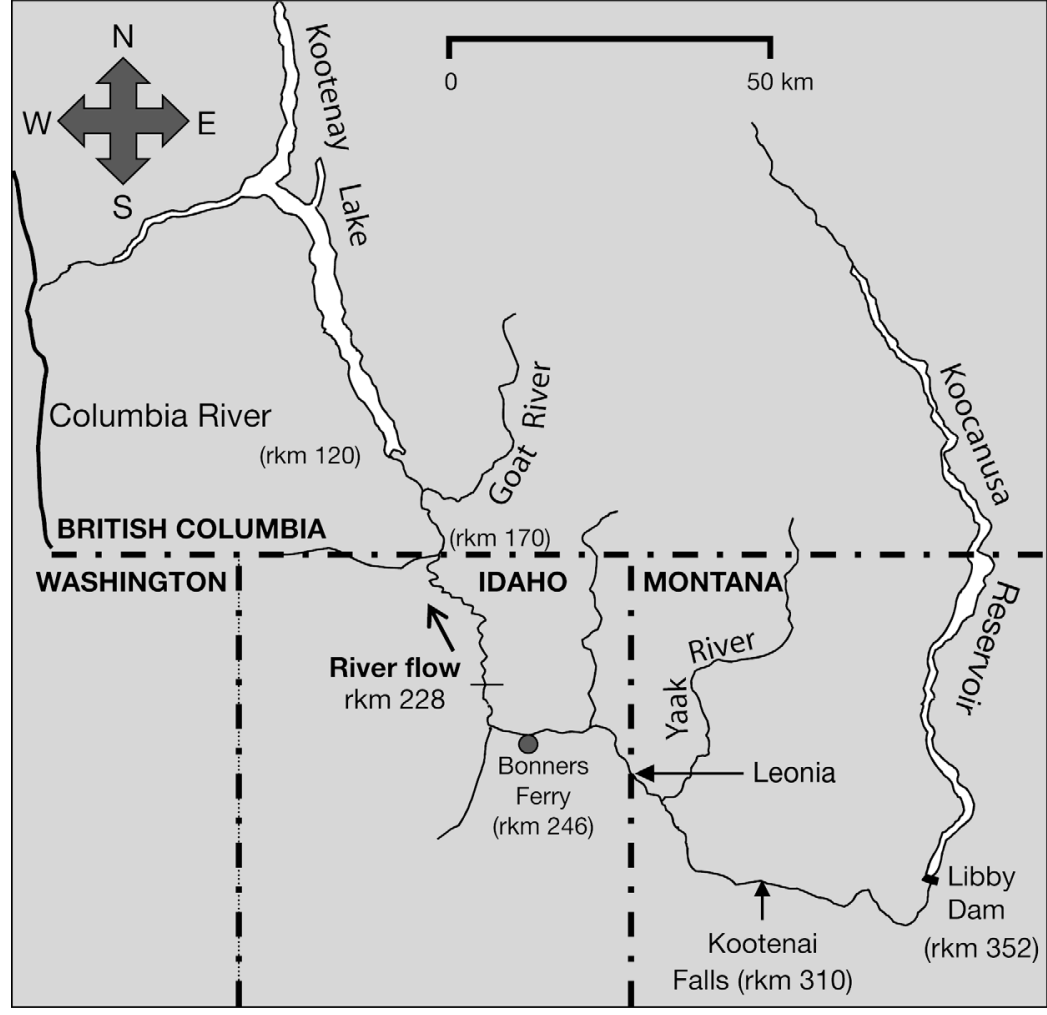

Fig. 1. Location of the Kootenai River, Kootenay Lake, Koocanusa Reservoir, Libby Dam, Bonners Ferry, the Columbia River, and other points relevant to the analysis of Kootenai white sturgeon. The river distances are kilometers from the northernmost reach of Kootenay Lake

generally 250 to $450 \mathrm{~m}^{3} \mathrm{~s}^{-1}$ (Duke et al. 1999, their Fig. 2). Moreover, the river had temperatures that were $\sim 1^{\circ} \mathrm{C}$ cooler in the summer and $4^{\circ} \mathrm{C}$ warmer in winter (Partridge 1983), was less productive (Woods 1982, Snyder \& Minshall 1996), and had altered sediment transport (Barton 2004). Assessing pre-Libby Dam factors by assigning ages of white sturgeon to historic ecological changes was invalid because of the inability to accurately age Kootenai River white sturgeon by conventional means (fin rays; Paragamian \& Beamesderfer 2003).

The Kootenai River white sturgeon was listed as endangered in Idaho and Montana, USA, on 6 September 1994 through the US Endangered Species Act (ESA; USFWS 1994) and in Canada under the Species at Risk Act (DFO 2007). Under provisions of the ESA, an international multi-agency Kootenai River White Sturgeon Recovery Team (KRWSRT) was formed to develop and help coordinate implementation of the Recovery Plan (Duke et al. 1999). The primary decisionmaking and guiding agency was the US Fish and Wildlife Service

Lake (H. Andrusak \& M. A. Crowley, BC Ministry of Environment, unpublished). May \& Huston (1979) reported that white sturgeon were limited in numbers in the Kootenai River downstream of Kootenai Falls, Montana, with a set line catch of 6 white sturgeon in 1975 and 2 in 1976. Studies in Idaho began in 1978 and suggested that within a decade of the completion of Libby Dam, the white sturgeon population became recruitment limited (Partridge 1983, Apperson 1990).

Although other anthropogenic factors may have had an effect on the decline of white sturgeon e.g. contaminants, disconnection from the flood plain, nutrient loss, and channelization of the river (Woods 1982, Anders et al. 2002, Kruse \& Scarnecchia 2002, Coutant 2004), dam operations were thought to have had the most profound effect as they had led to habitat alteration and loss. The physical and chemical attributes of the river after the construction of Libby Dam changed dramatically from pre-dam conditions (Woods 1982, Partridge 1983, Snyder \& Minshall 1996). Historic pre-dam discharges during white sturgeon spawning varied from 1416 to $2832 \mathrm{~m}^{3} \mathrm{~s}^{-1}$, whereas peak runoff events post-completion were
(USFWS). The Idaho Department of Fish and Game (IDFG), Kootenai Tribe of Idaho (KTOI), Montana Fish, Wildlife, and Parks, and BC Ministry of Environment (BCME) provided biological input, and the Bonneville Power Administration, USACE, and BC Hydro provided hydrological technical recommendations. Three of the main recovery measures were to (1) reestablish a naturalized discharge pattern to help restore wild spawning, rearing, and recruitment (Fig. 2), (2) implement conservation aquaculture (Ireland et al. 2002a,b) to prevent extinction and a breeding plan to maintain genetic integrity (Kincaid 1993), and (3) enhance habitat. The recovery plan specified that population recovery would be indicated if a naturally produced year class of white sturgeon occurred in 3 different years during a $10 \mathrm{yr}$ period (only 3 of $10 \mathrm{yr}$ of discharge were anticipated to be necessary for recruitment; USFWS 1999), measured by capture of 20 Age-1 juveniles per annual year class. Early in the planning process, it was anticipated that providing the additional (augmented discharge above that provided before listing) spring discharge would soon result in recovery. 


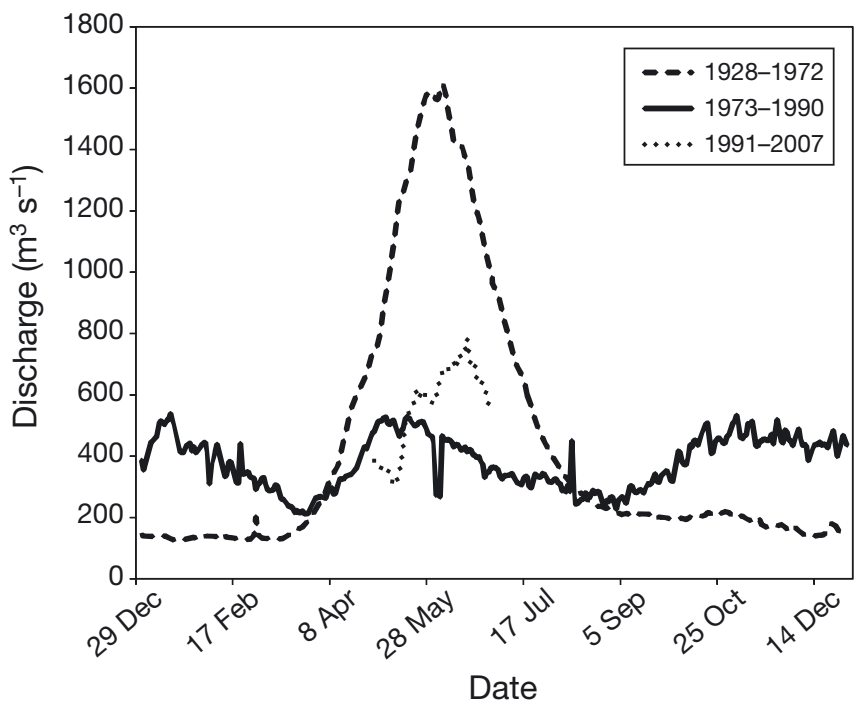

Fig. 2. Mean daily discharge patterns in the Kootenai River at Bonners Ferry, Idaho, from 1928 to 1972 (pre-Libby Dam), 1973 to 1990 (post-Libby dam), and 1991 to 2007 (post-Libby Dam with mitigated flows [mitigated discharges 1991-1993, prior to Kootenai River white sturgeon listing in US Endangered Species Act], May and June only)

The primary task of the IDFG was to provide relevant biological information regarding the status of white sturgeon, evaluate the effectiveness of experimental spring discharges, and determine environmental requirements for adequate spawning and recruitment of white sturgeon. With this information, it was believed that the KRWSRT could provide scientifically based recommendations to the USFWS and achieve recovery of the white sturgeon population. The underlying plan of the IDFG research program was to first develop a baseline of biological information and population vital statistics and then to investigate the relation of the biological to the environmental variables, including habitat needs and habitat changes. The biological data were based on Kootenai River white sturgeon movement and behavior, mark and recapture studies, investigation of habitat selection by adults under varying environmental conditions, egg collections, and documentation of spawning habitat. This was to be followed by early life history and juvenile white sturgeon studies.

\section{EARLY WHITE STURGEON DEMOGRAPHICS; POPULATION ESTIMATES}

The first population estimates for the US and Canadian portions of the Kootenai system reported in the late 1970s included 3000 to 5000 (Andrusak 1980) and 1148 white sturgeon (Partridge 1983). In the early 1990s, Apperson \& Anders (1991) estimated 880, followed by an estimate of 1469 by Paragamian et al. (1996) in the late 1990s. These estimates appeared to suggest that the population was relatively stable. Regardless, young fish were infrequently sampled and not recruiting to the population. More recent estimates of white sturgeon population numbers are given in 'White sturgeon demographics'.

\section{MIGRATION, SPAWNING, AND HABITAT}

An important question answered was how postLibby Dam natural- and human-related activities changed environmental variables that affected white sturgeon migration and behavior patterns following completion of Libby Dam. From 1991 to 1997, female and male white sturgeon were tagged with radio and sonic transmitters; telemetry records were used to examine pre-spawn movements and determine how fluctuations in river discharge, river stage, water temperature, and degree-days influenced migrations (Paragamian \& Kruse 2001, Paragamian et al. 2002). Concurrent to the migration studies, white sturgeon spawning frequency and locations were documented by collecting embryos (eggs) using artificial substrate mats (McCabe \& Beckman 1990).

\section{Migration}

Each autumn and spring, Kootenai River white sturgeon adults followed a 'short 2-step' migration pattern (Bemis \& Kynard 1997) moving from the lower river and Kootenay Lake, BC, to staging reaches in Idaho and then to spawning locations downstream of Bonners Ferry, Idaho (Fig. 1). As river stage rose and temperature increased, adult white sturgeon typically migrated to the post-Libby Dam spawning reach (river $\mathrm{km}, \mathrm{rkm}, 228.0$ to 246; Paragamian \& Kruse 2001, Paragamian et al. 2001).

Movement of female white sturgeon was more consistent and appeared to be more sensitive to increases in water temperature, river stage, and river discharge, and females were more useful than males in predicting the probability of migrations to the spawning reach (Paragamian \& Kruse 2001). Temperature was the most important variable in predicting female migration from a staging reach to the spawning reach, with an average migration temperature of about $8.0^{\circ} \mathrm{C}$; males migrated at lower temperatures. A logistic regression model based on telemetry data was developed that combined river 
temperature with river stage, and was used as a management tool to predict the probability of female sturgeon spawning migration (Paragamian \& Kruse 2001). For example, if the management objective was to initiate female white sturgeon spawning migration, and ambient river temperature was $6^{\circ} \mathrm{C}$, river stage $16.8 \mathrm{~m}$, and reservoir mid-surface temperature was $10^{\circ} \mathrm{C}$, then the model predicted an $85 \%$ probability that white sturgeon would migrate if mitigated discharges could increase water temperature at Bonners Ferry to $9.6^{\circ} \mathrm{C}$ and river stage to $18.0 \mathrm{~m}$.

\section{Spawning and habitat}

An important result of the migration studies was that spawning occurred shortly after female white sturgeon arrived within the spawning reach, as evidenced by the collection of embryos (Paragamian et al. 2001). White sturgeon embryos were collected every year from 1994 through 2002, demonstrating that spawning was taking place (Table 1). Total annual embryo collections varied from 75 in 1997 to 483 in 1998, with a range in catch per unit of effort (CPUE, where a unit of effort was one $24 \mathrm{~h}$ set of an egg sampling mat) of 0.018 in 1997 to 0.785 in 1998. Egg collections and CPUE were not necessarily good measures of adult spawning effort because many of the egg collection mats collected no embryos, while 1 mat could collect over 100 embryos if it was in the proximity of a spawning female. Only 1 larva was collected with many hours of D-ring and conical $0.5 \mathrm{~m}$ net sets; this was collected by the Idaho Department of Fish and Game and was the only larva collected between 1994 and 2002. Although sampling for embryos and larvae continues through the present time, the effort and objectives of sampling have changed.

Table 1. Acipenser transmontanus. Summary of total sampling mat effort (d), total number of embryos collected, and catch per unit effort (CPUE), where a unit of effort was one $24 \mathrm{~h}$ set of an egg sampling mat

\begin{tabular}{|cccc|}
\hline Year & Mat effort $(\mathrm{d})$ & Total no. embryos & CPUE \\
\hline 1994 & 2401 & 213 & 0.0887 \\
1995 & 3278 & 162 & 0.0494 \\
1996 & 4448 & 349 & 0.7846 \\
1997 & 4256 & 75 & 0.0176 \\
1998 & 3759 & 483 & 0.1285 \\
1999 & 3387 & 184 & 0.0543 \\
2000 & 2676 & 186 & 0.0695 \\
2001 & 2823 & 139 & 0.0492 \\
2002 & 1805 & 296 & 0.1640 \\
\hline
\end{tabular}

Telemetry also indicated that individual sturgeon shifted their spawning location over the $10 \mathrm{~km}$ primary spawning reach, but each time (from 1991 through 1997), embryos were typically collected in sand and silt substrate, at water depths within the main channel usually exceeding $5 \mathrm{~m}$, water velocities of 0.5 to $1.0 \mathrm{~m} \mathrm{~s}^{-1}$, and water temperatures between 8.5 and $12^{\circ} \mathrm{C}$ (Paragamian et al. 2001). Most of these characteristics differ from typical white sturgeon spawning habitat in the Columbia River where they have been found to spawn over cobble and gravel at warmer temperatures (Parsley et al. 1993, McCabe \& Tracy 1994). Only depth of spawning (>4 m) by Kootenai River white sturgeon conformed to Habitat Suitability Indices for white sturgeon in the Columbia River (Parsley et al. 1993). Spawning of Kootenai River white sturgeon in suboptimal habitat was in contradiction to the survival strategy of spawning over cobbles and gravels, which provides better survival chances for embryos and larva (Brannon 1984). White sturgeon release embryos that soon become adhesive for the purpose of adhering to coarse substrates. Many of the embryos collected were coated in sand, but this did not appear to affect development (Paragamian et al. 1996, 1997). Brannon (1984) believed that adhesion of embryos to cobble and gravel benefits survival of white sturgeon larvae by placing them in proximity to cover after hatching and prevents suffocation by fine sediments, but in the Kootenai River they may become buried within large mobile sand dunes (Paragamian et al. 1998) and as little as a few millimeters of sediment can cause suffocation (Kock et al. 2006). Research into white sturgeon movements and spawning habitat not only answered questions but revealed more curious behavior; why did white sturgeon spawn within unsuitable habitat for incubation and rearing (sand substrate) when there were more suitable conditions above Bonners Ferry?

\section{Spawning frequency, temperature, and discharge}

After the onset of white sturgeon spawning, the temporal distribution of the spawning events (determined by temperature, Beer 1981; and identified by the developmental stage of embryos, Wang et al. 1985) appeared to be dependent on the relative stability of temperature and changes in discharge (Paragamian \& Wakkinen 2002, 2011). Discharges in the Kootenai River at Bonners Ferry during spawning varied from 285 to $1155 \mathrm{~m}^{3} \mathrm{~s}^{-1}$ (Paragamian \& Wakkinen 2011). The years or periods of spawning 
within a year with the most spawning events were associated with temperatures that were stable or increasing, or changes were moderate (increases or decreases of $\leq 0.7^{\circ} \mathrm{C}$, which occurred in 1995,1996 , and 1998). The most consistent year for recorded spawning events was 1996, when spawning occurred over a period of 18 of 19 monitored days. Asynchronous spawning occurred during years when there were several rapid decreases in temperature of up to $2{ }^{\circ} \mathrm{C}$ over a $2 \mathrm{~d}$ period or a rapid decrease in discharge (1994, 1995, 1999, and 2000). Analysis suggested that discharges for optimum white sturgeon spawning in the Kootenai River should be held above $630 \mathrm{~m}^{3} \mathrm{~s}^{-1}$ and at a water temperature range of 9.5 to $12.5^{\circ} \mathrm{C}$ (Paragamian \& Wakkinen 2002).

Perhaps thought to be the most important measure committed to recruitment of wild white sturgeon was the implementation of the spawning pulse (augmentation of discharge beyond what was released prior to listing). Given the range of discharges during which spawning was documented, no evidence suggested a need for discharges higher than $1300 \mathrm{~m}^{3} \mathrm{~s}^{-1}$ (Paragamian et al. 2001). This raised a further question as to why the white sturgeon spawning pulse was necessary, other than for discharge above a minimum $\left(630 \mathrm{~m}^{3} \mathrm{~s}^{-1}\right)$ needed for spawning and other undocumented ecosystem benefits (Ward \& Stanford 1979). Because of legal commitment to the Biological Opinion (USFWS 2006) and the time which river managers had consequently spent on planning and implementing it (not discussed further here but see USFWS 2006), the sturgeon spawning pulse measure was a signifcant one which provoked much analysis and discussion.

\section{Evaluation of the white sturgeon pulse}

The IDFG's annual obligation with regard to the white sturgeon spawning pulse was to evaluate the response of adults expected to spawn and the timing and magnitude of spawning to the augmented discharge for spawning (Fig. 3). The white sturgeon spawning pulse was found to have little benefit to initiating spawning (Paragamian \& Wakkinen 2011). Observed spawning events of Kootenai River white sturgeon from 1994 to 2002 were examined to evalu- ate the effects of river discharge augmentation from Libby Dam and temperature on spawn timing. White sturgeon discharge augmentation from Libby Dam occurred in 6 of the 9 study years to enhance spawning conditions; there was no discharge augmentation in 1996, 2001, or 2002 (although augmented discharge in 1996 would have been unnecessary because of the high runoff volume). White sturgeon embryos collected and examined for developmental stage for earlier studies (Paragamian et al. 2001) were used to estimate the initial date of spawning. Spawning was likely independent of timing of discharge augmentation from Libby Dam because in 4 of 6 years initial spawning occurred prior to the commencement of discharge augmentation from the dam. Initiation of spawning began after the highest river discharge in 4 of 9 study years, and in each of those years occurred 2 to $11 \mathrm{~d}$ after the peak discharge. Linear regression analysis showed a significant relationship between the 9 (1994-2002) mean daily values for discharge and temperature and the onset of spawning. Results of logistic regression analysis suggested that the probability of predicting a spawning event was influenced by day-of-year, mean daily temperature, mean daily discharge, and the change in discharge over the previous $7 \mathrm{~d}$ (Paragamian \& Wakkinen 2011). The highest probability of spawning (0.48) was for the temperature interval 9.5 to $9.9^{\circ} \mathrm{C}$, and $93 \%$ of the observed spawning events occurred above $8^{\circ} \mathrm{C}$, similar to a previous study (Paragamian \& Wakkinen 2002). Of

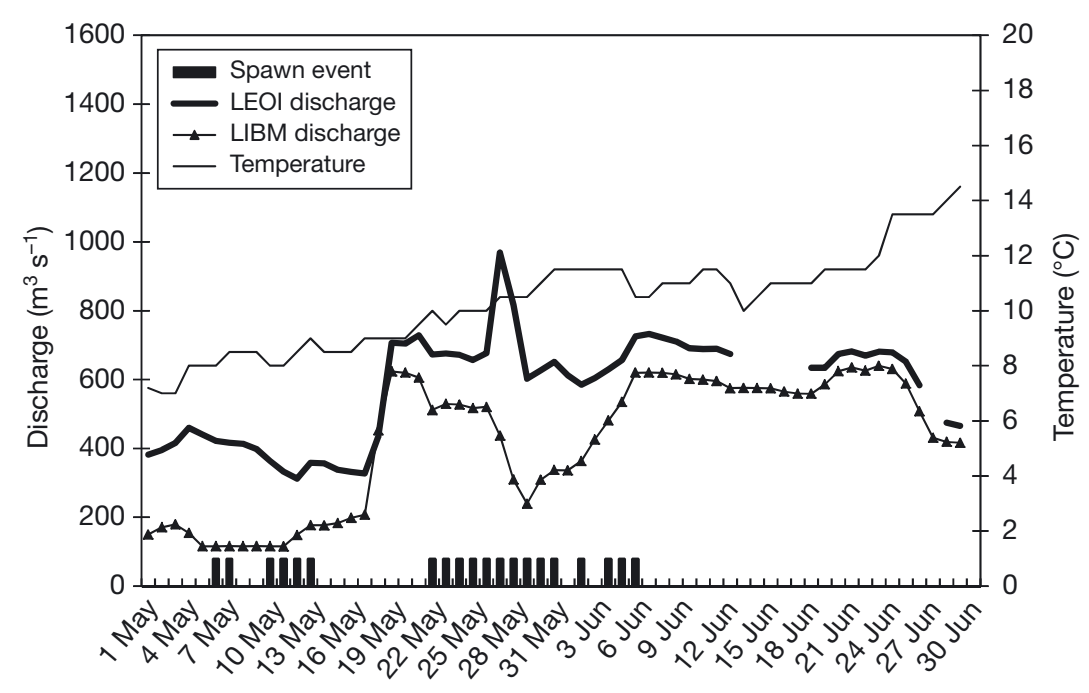

Fig. 3. Average daily discharge at Libby Dam (LIBM) and Leonia (LEOI), average daily temperature at Bonners Ferry, and estimated spawning events during May and June 1998 in the Kootenai River at Leonia, river km 270 (from Paragamian \& Wakkinen 2011). Note the 'sturgeon pulse' spike in discharge in mid-May 
the observed spawning events $63 \%$ occurred at discharges of at least $630 \mathrm{~m}^{3} \mathrm{~s}^{-1}$, although the probability of spawning was 1.0 for many different discharge levels, ranging from 164 to $1155 \mathrm{~m}^{3} \mathrm{~s}^{-1}$. Minor fluctuations in temperature and discharge characteristics had little additional predictive benefit once the above threshold values for those variables were met.

\section{Analytical fusion of spawning location and fluvial processes}

The spawning location of Kootenai River white sturgeon inspired differences of opinion within the KRWSRT. The present spawning location appeared to limit successful survival of embryos and larvae (Paragamian et al. 2001). More suitable spawning substrates of cobble and gravel begin at Bonners Ferry and extend upstream from rkm 244.6, where a limited amount of spawning takes place (Paragamian et al. 2009). Furthermore, it was not known where Kootenai River white sturgeon spawned pre-Libby Dam, and some KRWSRT members believed that they spawned in the more suitable reach of the river farther upstream, while others believed that the traditional spawning location could have been below Kootenai Falls ('the sturgeon hole') in Montana. Could spawning site selection have been an evolutionary trait inherited over $10000 \mathrm{yr}$ of segregation from other white sturgeon (Northcote 1973)? Were the fish compelled to spawn there because historic habitat was unavailable, because of false environmental cues, or because of an unknown factor?

Changing environmental conditions in the Kootenai River during the spawning season were one possible explanation for triggering the constant relocation response by white sturgeon during spawning. One variable that also continuously changed was river discharge, part of which was due to planned augmented discharges from Libby Dam. The changing discharge varied velocities in the river at different depths (McDonald et al. 2010). The Kootenai River is regulated, but the augmented sturgeon pulses were only about $60 \%$ of pre-dam spring discharge at Bonners Ferry, and velocities at spawning locations were usually less than $1 \mathrm{~m} \mathrm{~s}^{-1}$ (Paragamian et al. 2001). Parsley (1991) indicated that inadequate river velocities may limit the spawning of white sturgeon in the Columbia River. Parsley et al. (1993) suggested that high current velocities are crucial for white sturgeon for spawning and that coarse substrates are the result of the sorting of particles by higher velocities. If sturgeon were searching for spe- cific velocities as a spawning cue, they might be finding them in a reach of the Kootenai River with unsuitable spawning substrates.

It became increasingly evident that biological data and elementary analysis of environmental conditions alone were insufficient to resolve the questions of white sturgeon spawning location. A more sophisticated approach was necessary (Paragamian et al. 2009, McDonald et al. 2010). Fisheries and hydrology researchers collaborated to determine whether the spawning habitat had been changed by Libby Dam operations. Researchers modeled and compared velocities, sediment transport, and bathymetry with post-Libby Dam white sturgeon embryo collection locations. Substrate coring studies confirmed that there were cobbles and gravel substrates in most of the spawning locations but that these were buried under $\geq 1 \mathrm{~m}$ of post-Libby Dam sediment. Analysis suggested that Kootenai River white sturgeon spawned in areas of highest available velocity and depths over a range of discharges. Regardless of the discharge, the locations of accelerating velocities and maximum depth did not change and spawning locations remained consistent. Kootenai River white sturgeon were likely spawning in the same locations as pre-dam, but post-Libby Dam water management has reduced velocities and shear stress, thus sediment is now covering the cobbles and gravels. In 2006, an unforeseen runoff event caused the river at Bonners Ferry to approach $1600 \mathrm{~m}^{3} \mathrm{~s}^{-1}$, and underwater video confirmed the model with the documentation of cobbles and gravels at most spawning locations. Modeling suggested that higher discharges approximating $1600 \mathrm{~m}^{3} \mathrm{~s}^{-1}$ or more for a period of 2 wk would likely provide more suitable spawning and rearing conditions (Paragamian et al. 2009, McDonald et al. 2010).

\section{CONTAMINANTS}

In addition to physical habitat changes in the Kootenai River, introduction of contaminants into the river has been implicated as a possible cause of poor reproductive success for white sturgeon (Kruse \& Scarnecchia 2002). The exposure of gametes to contaminants during fertilization and early development could result in disruption of embryo development. The goal of a preliminary experiment (Kruse \& Scarnecchia 2002) was to determine whether treatments of various de-adhesion media affected contaminant uptake and survival of white sturgeon embryos. Eight metals (selenium, cooper, iron, zinc, 
magnesium, cadmium, lead, arsenic) and 2 organochlorine compounds (DDE and PCB Aroclor 1260) were used in the study and were detected in embryos used in the experiment. Uptake of some metals (e.g. arsenic, cadmium, copper, iron, magnesium, and lead) was significantly different between and among treatments and controls. It was hypothesized that river-bottom sediments may be a more significant route for uptake compared to water and suspended solids. It was also concluded that copper and Aroclor in the rearing media (primarily associated with riverbottom sediment) potentially decrease the survival and incubation time of white sturgeon embyros. Although the mortality rate of Kootenai River white sturgeon embryos in relation to contaminant exposure was not excessive, it may be an additional stress on viable reproduction. More controlled laboratory studies were recommended (Kruse \& Scarnecchia 2002) using additional parental fish to establish relationships between actual bioavailable and bioaccumulated contaminant concentrations and survival of embryonic sturgeon. However, these recommended studies have not been attempted at this time.

\section{TRANSLOCATION OF ADULTS}

Translocation of adult white sturgeon was undertaken to introduce mature fish to more suitable incubation and rearing habitat in the reach upstream of Bonners Ferry (Rust 2011). In 2003 and 2004, 25 mature white sturgeon were dual tagged with sonic and radio transmitters, and translocated approximately $50 \mathrm{~km}$ upstream of the post-Libby Dam spawning reach known as the canyon reach. The release site was characterized by having a higher gradient and primarily cobble and gravel substrate in comparison to the documented spawning location. Residence times for translocated sturgeon varied among years and sex but were difficult to assess because of the limited amount of telemetry data. In 2003, 7 of 9 males and 2 of 3 females released moved downstream within $2 \mathrm{~d}$ of release, while 1 female remained in the reach for $13 \mathrm{~d}$ and the 2 remaining males moved downstream within 4 d. However, 5 embryos were collected on 1 substrate mat (rkm 261.6) in 2003 but were too early in developmental stage to verify fertilization. In 2004, adults were released in an early and late period with only 1 female in the early release group. Three of the 6 males released in the early group stayed in the canyon reach for over $3 \mathrm{wk}$, the longest of any group. Combining years, males stayed in the canyon reach longer than females, sturgeon released early in the spawning season stayed in the reach longer, and releasing sturgeon in groups or in areas where other white sturgeon were currently residing may increase the residency in the study reach.

\section{RELEASE OF HATCHERY-REARED WHITE STURGEON}

\section{Hatchery intervention}

The conservation aquaculture program was expected to be an important recovery measure to prevent extinction and was combined with a breeding plan to maintain genetic integrity using wild brood stock. The goal was to restore the white sturgeon population to self-sustaining and to have it down- or delisted from the endangered species list. However, initially there were other important questions that needed answers. The breeding plan was developed first (Kincaid 1993, USFWS 1999) followed by experimental spawning and rearing in 1990 (Apperson \& Anders 1990), when sperm and eggs from adults were collected for a white sturgeon hatchery operated by the KTOI. Key objectives were to determine whether Kootenai River white sturgeon could produce viable offspring (there were elevated levels of copper in the oocytes, Apperson 1991) and whether these fish could be cultured with river water. By 1995, the aquaculture program developed into a viable measure, with the releases of 1000s of young white sturgeon annually (Ireland et al. 2002a).

Evaluation of the conservation aquaculture program began in 1993, when gill nets were deployed by the IDFG and BCME from Kootenay Lake, BC, to Bonners Ferry, to capture hatchery-reared and wild juvenile fish (Ireland et al. 2002a,b). Nearly all juveniles recently sampled were of hatchery origin, produced from Kootenay River brood stock. Evaluation was based on comparisons of estimates of survival, growth, and body condition between released and recaptured fish (Ireland et al. 2002b). Survival of hatchery-reared sturgeon was higher than expected (10\%, Kincaid 1993), and recruitment of wild fish was extremely low (Ireland et al. 2002b). Hatcheryreared white sturgeon were found to have a survival of about $60 \%$ in the first year after being released at age 1 or 2, and about $90 \%$ in the following years (up to $8 \mathrm{yr}$; Ireland et al. 2002b). Growth rates of hatchery-reared fish were acceptable, but slower than growth of wild sturgeon found in other rivers (Ireland et al. 2002a). 
Analysis of the DNA of the white sturgeon broodstock used from 1993 to 2002 indicated that the genetic makeup of the hatchery-produced fish was similar to that of wild fish (P. Anders pers. comm.). However, the minimum population viability number $\left(\mathrm{N}_{\mathrm{e}}\right)$ of the hatchery brood stock varied from 2 to 15.5 (P. Anders pers. comm.), which was substantially less than the minimum desired number of 50 spawning adults.

Hatchery production and survival were an important component of an overall reassessment of the white sturgeon stock (Paragamian et al. 2005, Beamesderfer et al. 2009). Hatcheryreared juvenile white sturgeon became abundant, by the mid-1990s outnumbering wild juvenile white sturgeon in the gill-net catch by about 400:1. With the advent of hatchery releases in 1990, significant annual releases projected from 2000 through the foreseeable future, and no additional natural recruitment, resulted in the expectation that significant numbers of hatchery white sturgeon would begin recruiting to the adult population after 2020 (Fig. 4). It was (and still is) expected that the adult population would rapidly increase from 2020 to 2030, after which it was projected to stabilize to about 3000 white sturgeon. This population number would be approximately 5 times the current adult population number and just under half the total number estimated in 1980 (Partridge 1983). Further evaluations of hatchery white sturgeon by 2008 suggested that stocking more and smaller hatchery progeny resulted in density-dependent mortality and lower survival (Justice et al. 2009), and dispersal of hatchery fish from release sites was thought to be substantial (Neufeld \& Rust 2009).

\section{Embryos and larvae}

Release of embryos and larvae began in 2001 with the release of $135000 \sim 5 \mathrm{~d}$ old larvae (Paragamian et al. 2003). Sampling $0.5 \mathrm{~km}$ downstream of the release site (rkm 262.2) with D-ring and
$0.5 \mathrm{~m}$ nets resulted in a total catch of 97 larvae within a few hours of their release. The first experiment validated that the gear used for sampling wild white sturgeon larvae would be effective if they were present. Additional releases of larvae and embryos occurred through the 2000s to evaluate habitat and stocking location and timing. However, to date, only 1 larva has been recaptured, but at that time studies were still inconclusive (Rust \& Wakkinen 2008).
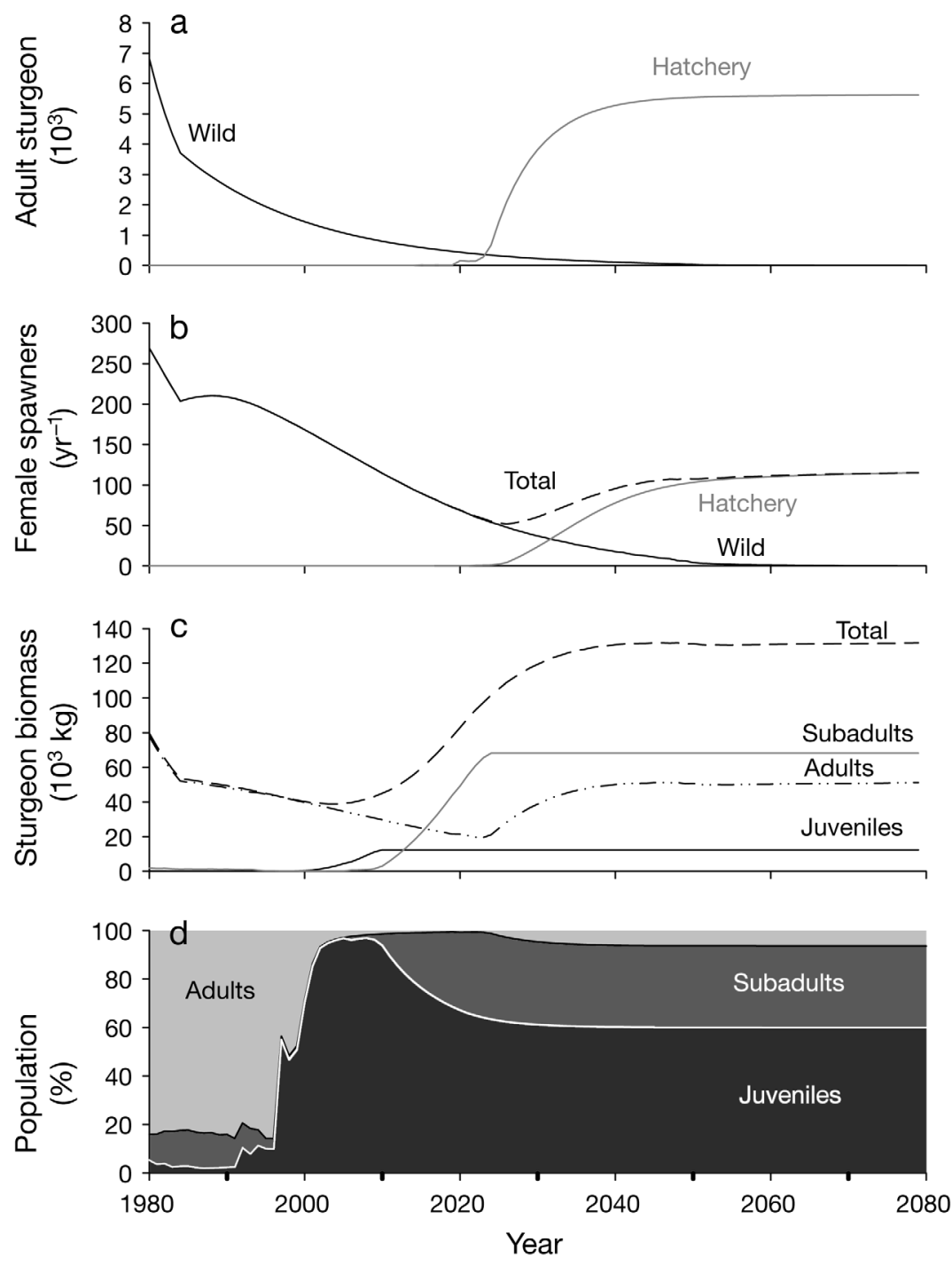

Fig. 4. Acipenser transmontanus. Kootenai River white sturgeon population trajectories based on mark and recapture population estimates from 1980 through 2004, releases of hatchery-reared white sturgeon from 1990 through 2000 , projected number of hatchery releases through 2080, and simulated modeling numbers through 2080. (a) Simulated total population numbers of wild and hatchery white sturgeon, (b) wild and hatchery female spawner numbers, (c) biomass of hatchery and wild white sturgeon juveniles, subadults, adults (wild and hatchery fish combined) and total, and (d) population number of juveniles, subadults, and adult (wild and hatchery) (Paragamian et al. 2005) 


\section{WHITE STURGEON DEMOGRAPHICS (POST 2000)}

\section{Population vital statistics}

Detailed examinations of the Kootenai River white sturgeon stock status were not undertaken until the early 2000s, although mark and recapture records including lengths, weights, and capture dates and locations had been archived since the late 1970s (Paragamian et al. 2005; Fig. 4). The early estimates of white sturgeon abundance were biased with regard to sample locations, time of sampling, artifacts of models, and assumptions (Paragamian et al. 2005, Beamesderfer et al. 2009). The recent results were not unexpected; Kootenai River white sturgeon had reached critically low population numbers where genetic and demographic risks are significant (Paragamian \& Beamesderfer 2004). Paragamian et al. (2005) estimated that only 630 adults remained in 2002 from a population 10 times that size just $20 \mathrm{yr}$ prior. This estimate was more recently revised to account for bias, and suggested that about 1000 fish remained and that there was a low total annual mortality of $4 \%$ for adults (Beamesderfer et al. 2009). Recruitment failures continued to drive the Kootenai River white sturgeon population toward extinction, with an estimated annual recruitment of 10 Age-1 fish annually with a high of 7 wild Age-1 sturgeon caught in 2007 (Rust \& Wakkinen 2008). No significant recruitment of juvenile sturgeon had occurred since at least 1974, and consistent recruitment had not occurred since at least 1965.

\section{Examination of recovery goals}

Because recovery criteria from the Kootenai River White Sturgeon Recovery Plan were based on preliminary information, it was important to revaluate criteria with more recent demographic data (Paragamian \& Hansen 2008). Demographic statistics (Paragamian et al. 2005) and a stochastic simulation model were used to estimate population growth and time to recovery in relation to a simulated range of recruitment rates. The recovery plan specified that population recovery would be indicated if a naturally produced year class of white sturgeon occurred in 3 different years during a $10 \mathrm{yr}$ period (only 3 of $10 \mathrm{yr}$ of discharge were anticipated to be suitable for recruitment; USFWS 1999), measured by capture of 20 Age-1 juveniles per year class. This study differed from a previous study that quantified population demographics, the decline in numbers of wild fish, and expected recruitment of hatchery-origin juveniles to the adult population (Paragamian et al. 2005), by focusing only on the fate of wild-origin fish. The focus on wild fish was justified based on the following: down- or delisting of the population must be based on the status of wild-origin fish (Duke et al. 1999); genetic contribution of hatchery-origin fish is not clear and cannot be known until fish mature (Paragamian \& Beamesderfer 2004); and reproductive ability of hatchery-origin fish is uncertain (Smith et al. 2002).

Demographic modeling of the archived and published data (Paragamian et al. 2005, Paragamian \& Hansen 2008) suggested that the target recruitment rate in the recovery plan for white sturgeon in the Kootenai River would only slowly rebuild the population, a result not yet established. For example, if year classes of a target size are only produced in 3 of $10 \mathrm{yr}$ (annual recruitment $=0.12$ ), as stipulated in the recovery plan (Duke et al. 1999), the population would only consist of about 1200 individuals after $25 \mathrm{yr}$, i.e. only 2.4 times more individuals than were present in 2005. In contrast, if year classes of the target size are produced only every other year (annual recruitment $=0.20$ ), the population would consist of about 4000 individuals after $25 \mathrm{yr}$, an increase of 8 times (Paragamian \& Hansen 2008). Better still, if year classes of the target size are produced every year (annual recruitment $=0.41$ ), the population would consist of nearly 7000 individuals after $25 \mathrm{yr}$, i.e. the number that were present before the population suffered recruitment failure. Therefore, it was recommended to increase the recruitment target in the recovery plan to 0.41 Age- 1 recruits per adult, to reduce the time for population rebuilding and setting the timeline for recovery at 25 yr to permit progeny from wild-origin parents to mature and spawn. It was further recommended to increase the minimum recruitment rate to detection of at least 20 wild-origin juveniles from each year class reaching $1 \mathrm{yr}$ of age in each of $10 \mathrm{yr}$ (total annual recruitment of at least 400 fish), the recruitment rate that would rebuild the population to nearly 7000 individuals within $25 \mathrm{yr}$ (Paragamian \& Hansen 2008).

Under the present recruitment limitations, recovery of white sturgeon in the Kootenai River will depend primarily on improving first-year survival. It was concluded that future improvement in recruitment and first-year survival of white sturgeon in the Kootenai River must rely on habitat enhancement to improve incubation and rearing conditions (Duke et al. 1999, Paragamian et al. 2005). 


\section{RECOMMENDATIONS}

To date, no measure has led to successful recruitment of the Kootenai River white sturgeon, and population viability is still compromised. Only the very long lifespan of the white sturgeon has forestalled its extinction in the Kootenai River. The white sturgeon spawning pulse was shown to be of little value to initiation of spawning. Thus, immediate prospects for restoring natural recruitment remain uncertain. Discharge augmentation during spring may have stimulated sturgeon spawning behavior. Embryos are collected in most years, but habitat changes and spawning locations are unfavorable to egg survival. Although higher discharges approximating $1600 \mathrm{~m}^{3}$ $\mathrm{s}^{-1}$ or more for a period of $2 \mathrm{wk}$ would likely provide more suitable spawning and rearing conditions in the present white sturgeon spawning locations, this would be socially and politically unacceptable because it would bring the river elevation to $\geq 537.66 \mathrm{~m}$, i.e. flood stage. Thus, support should be given to habitat modifications incorporated into a management plan to restore suitable substrates and ensure better survival of embryos and larvae not only in the present spawning location, but also in prospective spawning locations upstream of Bonners Ferry (KTOI 2009).

Acknowledgements. Special thanks to Pete Rust, Dan Schill and Diane Wakkinen of the Idaho Department of Fish and Game. We also thank the following people for their assistance with data collection: Colin Spence, Don Miller, and Matt Neufeld of the British Columbia Ministry of Environment; Sue Ireland, Jack Siple and many others with the Kootenai Tribe of Idaho; and Gary Barton and Mike Parsley of the United States Geological Survey. The Bonneville Power Administration provided funding for this work.

\section{LITERATURE CITED}

Anders PJ, Richards DL, Powell MS (2002) The first endangered white sturgeon population: repercussions in an altered large river-floodplain ecosystem. In: Van Winkle W, Anders P, Secor DH, Dixon DD (eds) Biology, management, and protection of North American sturgeon. Am Fish Soc Symp 28, Bethesda, MD, p 67-82

Andrusak H (1980) Kootenay River white sturgeon. British Columbia Ministry of Environment, Nelson

Apperson KA (1990) Kootenai River white sturgeon investigations and experimental culture. Annual Progress Report FY1989. Report to Bonneville Power Administration. Idaho Department of Fish and Game, Boise, ID

Apperson KA (1991) Kootenai River white sturgeon investigations and experimental culture. Annual Progress Report FY1990. Report to Bonneville Power Administration. Idaho Department of Fish and Game, Boise, ID

Apperson K, Anders PJ (1990) Kootenai River white sturgeon investigations and experimental culture. Annual Progress Report, Project 88-65. Prepared for Bonneville
Power Administration. Idaho Department of Fish and Game, Boise, ID

Apperson K, Anders PJ (1991) Kootenai River white sturgeon investigations and experimental culture. Annual Progress Report, Project 88-65. Prepared for Bonneville Power Administration. Idaho Department of Fish and Game, Boise, ID

Barton GJ (2004) Characterization of channel substrate, and changes in suspended sediment transport and channel geometry in white sturgeon spawning habitat in the Kootenai River near Bonners Ferry, Idaho, following the closure of Libby Dam: Water-Resources Investigation Report 03-4324. US Geological Survey, Tacoma, WA

Beamesderfer RCP, Justice C, Paragamian VL, Rust P, Ireland S (2009) Kootenai sturgeon population status update. Report to Kootenai River Recovery Team and Bonneville Power Administration. S. P. Cramer and Associates, Gresham, OR

Beer KE (1981) Embryonic and larval development of white sturgeon (Acipenser transmontanus). MS thesis. University of California, Davis, CA

Bemis WE, Kynard B (1997) Sturgeon rivers: an introduction to acipenseriform biogeography and life history. Environ Biol Fishes 48:167-184

Brannon EL (1984) Columbia River white sturgeon (Acipenser transmontanus) early life history. PhD thesis, University of Washington, Seattle, WA

Coutant C (2004) A riparian habitat hypothesis for successful reproduction of white sturgeon. Rev Fish Sci 12:23-73

DFO (Fisheries and Oceans Canada) (2007) Recovery potential assessment for white sturgeon. Science Advisory Report 2007/014. DFO Canadian Scientific Advisory, Ottawa

Duke S, Anders P, Ennis G, Hallock B and others (1999) Recovery plan for Kootenai River white sturgeon (Acipenser transmontanus). J Appl Ichthyol 15:157-163

Ireland SC, Anders PJ, Siple JT (2002a) Conservation aquaculture: an adaptive approach to prevent extinction of an endangered white sturgeon population. In: Van Winkle W, Anders P, Secor DH, Dixon DD (eds) Biology, management, and protection of North American sturgeon. Am Fish Soc Symp 28, Bethesda, MD, p 211-222

Ireland SC, Siple JT, Beamesderfer RCP, Paragamian VL, Wakkinen VD (2002b) Success of hatchery-reared juvenile white sturgeon (Acipenser transmontanus) following release in the Kootenai River, Idaho. J Appl Ichthyol 18: 642-650

> Justice C, Pyper BJ, Beamesderfer RCP, Paragamian VL, Rust PJ, Neufeld MD, Ireland SC (2009) Evidence of density and size-dependent mortality in hatchery-reared juvenile white sturgeon (Acipenser transmontanus) in the Kootenai River. Can J Fish Aquat Sci 66:802-815

Kincaid H (1993) Breeding plan to preserve the genetic variability of the Kootenai River white sturgeon. Report (Project 93-27) to Bonneville Power Administration. US Fish and Wildlife Service, Portland, OR

Kock TJ, Congleton JL, Anders PJ (2006) Effects of sediment cover on survival and development of white sturgeon embryos. N Am J Fish Manag 26:134-141

Kruse GO, Scarnecchia DL (2002) Contaminant uptake and survival of white sturgeon embryos, Acipenser transmontanus. In: Van Winkle W, Anders P, Secor DH, Dixon DD (eds) Biology, management, and protection of North American sturgeon. Am Fish Soc Symp 28, Bethesda, MD, p 151-160 
KTOI (Kootenai Tribe of Idaho) (2009) Kootenai River habitat restoration project master plan: a conceptual feasibility analysis and design framework. Bonners Ferry, ID

May B, Huston J (1979) Status of fish populations in the Kootenai River below Libby Dam following regulation of the river. Final Job Report. Contract No. DACW 67-76-C-0055. Montana Department of Fish and Game, Helena, MT

McCabe GT, Beckman LG (1990) Use of an artificial substrate to collect white sturgeon embryos. Calif Fish Game 76:248-250

McCabe GT, Tracy CA (1994) Spawning and early life history of white sturgeon, Acipenser transmontanus, in the lower Columbia River. Fish Bull 92:760-772

McDonald RR, Nelson JM, Paragamian VL, Barton GJ (2010) Modeling the effect of flow and sediment transport on white sturgeon spawning habitat in the Kootenai River, Idaho. J Hydraul Eng 136:1077-1092

Neufeld MD, Rust PJ (2009) Using passive sonic telemetry methods to evaluate dispersal and subsequent movements of hatchery-reared white sturgeon in the Kootenay River. J Appl Ichthyol 25(Suppl 2):27-33

Northcote TC (1973) Some impacts of man on Kootenay Lake and its salmonids. Tech Rep No. 2. Great Lakes Fishery Commission, Ann Arbor, MI

> Paragamian VL, Beamesderfer RCP (2003) Growth estimates from tagged white sturgeon suggest that ages from fin rays underestimate true age in the Kootenai River, USA and Canada. Trans Am Fish Soc 132:895-903

Paragamian VL, Beamesderfer RCP (2004) Dilemma on the Kootenai River - the risk of extinction or when does the hatchery become the best option? Am Fish Soc Symp 44: 377-385

> Paragamian VL, Hansen MJ (2008) Evaluation of recovery goals for endangered white sturgeon in the Kootenai River, Idaho. N Am J Fish Manag 28:463-470

> Paragamian VL, Kruse G (2001) Kootenai River white sturgeon spawning migration behavior and a predictive model. N Am J Fish Manag 21:10-21

Paragamian VL, Wakkinen VD (2002) The effects of flow and temperature on the spawning of Kootenai River white sturgeon. J Appl Ichthyol 18:608-616

Paragamian VL, Wakkinen VD (2011) White sturgeon spawning and discharge augmentation. Fish Manag Ecol 18:314-321

Paragamian VL, Kruse G, Wakkinen VD (1996) Kootenai River white sturgeon investigations. Annual Progress Report FY 1995. Contract No. DE-AI79-88BP93497; Project No. 88-6. Prepared for US Department of Energy, Bonneville Power Administration. Idaho Department of Fish and Game, Boise, ID

Paragamian VL, Kruse G, Wakkinen V (1997) Kootenai River white sturgeon investigations. Annual Progress Report FY 1996. Contract No. DE-AI79-88BP93497; Project No. 88-6. Prepared for US Department of Energy, Bonneville Power Administration. Idaho Department of Fish and Game, Boise, ID

Paragamian VL, Kruse G, Wakkinen V (1998) Kootenai River white sturgeon investigations. Annual Progress Report FY 1997. Contract No. DE-AI79-88BP93497; Project No. 88-6. Prepared for US Department of Energy, Bonneville Power Administration. Idaho Department of Fish and Game, Boise, ID

Paragamian VL, Kruse G, Wakkinen V (2001) Spawning habitat of Kootenai River white sturgeon, post-Libby Dam. N Am J Fish Manag 21:22-33
Paragamian VL, Kruse G, Wakkinen V (2003) Kootenai River white sturgeon investigations. Annual Progress Report FY 2002. Contract No. DE-AI79-88BP93497; Project No. 88-6. Prepared for US Department of Energy, Bonneville Power Administration. Idaho Department of Fish and Game, Boise, ID

> Paragamian VL, Beamesderfer RCP, Ireland SC (2005) Status, population dynamics, and future prospects of the endangered Kootenai River white sturgeon population with and without hatchery intervention. Trans Am Fish Soc 134:518-532

Paragamian VL, McDonald R, Nelson GJ, Barton G (2009) Kootenai River velocities, depth, and white sturgeon spawning site selection - a mystery unraveled? J Appl Ichthyol 25:640-646

Parsley MJ (1991) How water velocities may limit white sturgeon spawning. Research Information Bulletin 91-86. US Fish and Wildlife Service, Washington, DC

Parsley MJ, Beckman LG, McCabe G Jr (1993) White sturgeon spawning and rearing habitat in the Columbia River downstream of McNary Dam. Trans Am Fish Soc 122:217-228

Partridge F (1983) Kootenai River fisheries investigations. Idaho Department of Fish and Game Federal Aid to Fish and Wildlife Restoration Job Completion Report F-73-R5, Boise, ID

Rust PJ (2011) Translocation of prespawn adult Kootenai River white sturgeon. J Appl Ichthyol 27:450-453

Rust P, Wakkinen D (2008) Kootenai River white sturgeon investigations. Annual Progress Report FY 2007. Contract No. DE-AI79-88BP93497; Project No. 88-6. Prepared for US Department of Energy, Bonneville Power Administration. Idaho Department of Fish and Game, Boise, ID

Simpson J, Wallace R (1982) Fishes of Idaho. University of Idaho Press, Moscow, ID

Smith TIJ, Collins MC, Post WC, McCord JW (2002) Stock enhancement of shortnose sturgeon: a case study. In: VanWinkle, Anders P, Secor DH, Dixon D (eds) Biology, management, and protection of North American sturgeon. Am Fish Soc Symp 28, Bethesda, MD

Snyder EB, Minshall GW (1996) Ecosystem metabolism and nutrient dynamics in the Kootenai River in relation to impoundment and flow enhancement for fisheries management. Completion Report. Stream Ecology Center, Idaho State University, Pocatello, ID

USFWS (US Fish and Wildlife Service) (1994) Determination of endangered status for the Kootenai River white sturgeon population. Fed Reg 59:45989-46002

USFWS (1999) Recovery plan for the Kootenai River population of the white sturgeon (Acipenser transmontanus). Region 1, USFWS, Portland, OR

USFWS (2006) Draft biological opinion, for operation of Libby Dam. Region 1, USFWS, Portland, OR

> Wang YL, Binkowski FP, Doroshov SI (1985) Effect of temperature on early development of white and lake sturgeon, Acipenser transmontanus and A. fulvescens. Environ Biol Fishes 14:43-50

Ward JV, Stanford JA (1979) The ecology of regulated streams. Plenum Press, New York, NY

Woods PF (1982) Annual nutrient loadings, primary productivity, and trophic state of Lake Koocanusa, Montana and British Columbia, 1972-1980. Geologic Survey Professional Paper 1238. United States Government Printing Office, Washington, DC 